\title{
Hisse Senedi Piyasası ve Döviz Kuru Mekanizmaları Üzerine Bir Panel Veri Analizi
}

\author{
Gönül YÜCE AKINCI ${ }^{*}$ \\ Fatma KÜÇÜKÇAYLI*
}

\section{$\ddot{O Z Z E T}$}

Bu çalışmada, hisse senedi piyasaları ve döviz kurları arasındaki ilişkiler 12 ülke itibariyle 1997:07-2013:12 dönemi için panel veri analizleri kullanılarak incelenmiştir. Değişkenler arasındaki eşbütünleşme ilişsisinin belirlenebilmesi amacıyla Pedroni ve Kao eşbütünleşme analizleri uygulanmış ve bulguları, ilgili değişkenler arasında uzun dönemli ilişkilerin geçerli olduğunu ortaya koymuştur. Bunun yanı sıra, değişkenler arasındaki nedensellik ilişkileri Granger nedensellik testi ile sınanmış ve beklentilerle uyumlu olan nedensellik ilişkilerinin varlı̆̆ kanıtlanmıştır. Nedensellik bulgularını destekleyen sabit etkili model tahmin sonuçları, döviz kurunun cari değerinin borsa endeksi üzerindeki etkisinin negatif ve istatistiki bakımdan anlaml olduğunu göstermiştir. Ayrıca, analizlerin sağlamlılığını gösterebilmek için modellere kontrol değişkenleri de ilave edilmiş ve faiz oranının cari ve bir dönem gecikmeli değerleri ile enflasyon oranın cari değerinin döviz kuru üzerinde istatistiki bakımdan anlaml pozitif yönlü baskl yaratan temel faktörler olduğu belirlenmiştir.

Anahtar Kelimeler: Hisse Senedi Piyasaları, Döviz Kurları, Panel Veri Analizi.

JEL Siniflandırmast: C33, G15, G23, F31.

\section{A Panel Data Analysis on the Mechanics of Stock Market And Exchange Rate ABSTRACT}

In this study, the relationships between stock markets and exchange rates are examined using panel data analysis in the period 1997:07-2013:12 in 12 countries. Pedroni and Kao cointegration analysis are applied to determine the cointegration relationship among the variables and the findings of the analysis show the validity of long-run relationships among the variables. Besides, the causality nexus among the variables is tested using Granger causality analysis and the causal linkages among the variables are found that are compatible with the expectations. The results of the fixed-effect estimation analysis supporting the causality findings point out that the current value of the exchange rate has a statistically significant negative effect on the stock market index. Furthermore, in order to show the robustness of the analysis some control variables are added to the regression models and it is determined that the current and one-lagged values of the interest rate and the current values of inflation rate are the main factors which create a statistically significant positive pressure on the exchange rate.

Keywords: Stock Markets, Exchange Rates, Panel Data Analysis.

Jel Classification: C33, G15, G23, F31.

\footnotetext{
Yrd. Doç. Dr. Gönül Yüce Akıncı, Ordu Üniversitesi, Ünye İktisadi ve İdari Bilimler Fakültesi, gyuce81@gmail.com

Yrd. Doç. Dr. Fatma Küçükçaylı, Mehmet Akif Ersoy Üniversitesi, Ağlasun Meslek Yüksek Okulu, fmumcu@mehmetakif.edu.tr
} 


\section{GIIRIŞ}

Dünya ekonomi tarihi, küreselleşme hareketleri kapsamında önemli gelişmeler sergilemiştir. İlk olarak mal ve finans piyasalarında etkisini gösteren ve 1870-1914 dönemini kapsayan süreçte ülkeler, emek ve sermaye akımlarına paralel olarak iktisadi küreselleşmenin temellerini atmaya başlamışlardır (Aslan, 2007: 7-8). 17. yüzyılın bir uzantısı olan ve geçerliliğini artırarak devam ettiren "bırakınız yapsınlar, bırakınız geçsinler" düşüncesi ile birlikte finansal piyasalar da gelişim evresine dahil olmuş ve mali entegrasyon, küreselleşme hareketlerinin ayrılmaz bir parçası olarak düşünülmeye başlamıştır (Taylor, 2004: 28).

1914-1945 dönemindeki buhran ve savaş yıllarının atlatılmasına paralel olarak ortaya çıkan bölgeselleşme ve entegrasyon hareketleri ikinci küreselleşme evresini hızlandıran temel faktörler olmuşlardır. Çok taraflı üretim, ticaret ve finansal ilişkilerin gelişmesi hem ikinci dalga küreselleşme eğilimlerine ivme kazandırmış ve hem de benzer özelliklere sahip olup da aynı coğrafi bölge içinde yer alan ülkeleri güç birliği ile yoğun bölgesel ilişkiler içerisine itmiş̧ir (Köse, 2003: 7). Bununla birlikte, 1970'li yıllarda patlak veren petrol şoklarının etkisiyle başta Batı ekonomileri olmak üzere dünyadaki birçok ülkeyi etkileyen stagflasyon olgusu, ABD dış ticaret açıklarının neden olduğu Bretton Woods sisteminin çöküşü, doların Avrupa'da işlem görmeye başlaması sonucunda euro-dolar ve euro-tahvil piyasalarının gelişmesi ile para ve sermaye piyasalarının ülkeler arasında bütünleşmesine paralel olarak 1980'lere gelindiğinde üçüncü küreselleşme dönemi başlamıştır (Aslan, 2007: 8). Ülkelerin birbirlerine olan bağllılklarının ticari, mali ve üretim yönünden artmasına neden olan bu son küreselleşme süreci, başta birbirleriyle çeşitli şekillerde entegrasyon hareketi oluşturan ülkeler olmak üzere bütün dünyanın dahil olduğu liberalleşme olgusunun yeniden hızlanmasına neden olmuştur (Dowrick ve DeLong, 2003: 192).

Finansal özgürlüklerin gelişmesi ve mali piyasaların küreselleşmesine bağlı olarak finansal piyasalara müdahale imkânının daha az olduğu serbest kur rejimine geçiş, gelişmekte olan ülkelerde finansal piyasaların istikrarının giderek artması ve yatırımcıların portföylerini oluştururken daha bilinçli kararlar alması yönündeki gelişmeler, ulusal ve uluslararası piyasalarda hisse senedi fiyatlarıyla döviz kuru arasındaki ilişkileri güçlendirmiştir. Bu gelişmeler yanında, mali piyasalarda yaşanan finansal krizler finans piyasası ile döviz piyasası ve reel piyasa arasındaki karşılıklı etkileşimi daha karmaşık hale getirmiş ve bu alanda yapılan araştırmaların öneminin ve sayısının artmasına neden olmuştur. Özellikle, ifade edilen piyasalar arasındaki ilişkinin yönü ve büyüklüğünün anlaşılması neticesinde uygulamaya konulacak olan optimum politika süreçlerinin belirlenmesi sadece kamusal ve özel kesim için değil, aynı zamanda bireysel yatırımcılar için de hayati bir değere sahip olabilmektedir. Diğer taraftan, ekonomi ve finans literatüründe ortaya konan uygulamalı çalı̧̧malar, hisse senedi piyasası ve döviz kuru arasındaki ilişkiyi açıklamaya yönelik hipotezler sunmakla birlikte, farklı gelişme düzeyine sahip ülkeler itibariyle farklı sonuçların elde edilmesine bağlı olarak ilgili konu bazında bir mutabakatın sağlanamadığ söylenebilmektedir. Dolayısıyla, menkul kıymet ve döviz piyasaları arasındaki muğlak 
ilişkinin açıklanabilme arzusu, konunun önemini daha fazla artırmaktadır. Literatürdeki ilgili açığı kapatabilmek adına menkul kıymet piyasaları ve döviz kuru arasındaki ilişki ilk olarak Franck ve Young (1972) tarafından ele alınmış ve hisse senedi fiyatları ile döviz kurları arasında anlamlı bir ilişki olmadığ 1 tespit edilmiştir.

Finans literatüründe, döviz kuru ve menkul kıymet piyasaları arasındaki ilişkiler temel olarak hisse senedi fiyatları ile döviz kuru arasındaki ilişkinin niteliği şeklinde ele alınmıştır. $\mathrm{Bu}$ kapsamda, ilgili değişkenler arasındaki karşılıklı bağlantıyı açıklayabilmek adına geleneksel ve portföy dengesi yaklaşımı olmak üzere iki teori oluşturulmuştur. Dornbusch ve Fisher (1980)'in geliştirdiği geleneksel yaklaşım, döviz kurundaki bir değişmenin hisse senedi fiyatlarını etkileyeceğini, başka bir ifadeyle, döviz kurundan hisse senedi fiyatlarına doğru bir nedensellik ilişkisi olduğunu ifade etmektedir. Geleneksel yaklaşıma göre, döviz kurunun değişmesi ile uluslararası rekabetçi yapı ve dış ticaret dengesi etkilenerek ülkenin gelir düzeyi ve firmaların hisse senedi fiyatlarında bir değişim oluşmaktadır. Sonuç olarak firmaların gelirleri ve hisselerinin fiyatlarının artması ile döviz kuru ve hisse senedi fiyatı arasında pozitif yönlü bir ilişki kendini göstermektedir (Berke, 2012: 244). Ayrıca, döviz kurundaki değişimlerin uluslararası nitelikli hisse senetlerini doğrudan ve yerel şirketler tarafından piyasaya ihraç edilen hisse senetlerini ise dolaylı olarak etkilediğini belirten Aggarwal (1981), kur değişimlerinin şirket kâr ya da zararı üzerinde bir etki yarattığını ve bu etkinin açıklanmasına bağlı olarak ilgili şirketin hisse senedi değerinin değiştiğini vurgulamıştır. Geleneksel yaklaşıma atıfta bulunan Aggarwal (1981), hisse senetleri ile döviz kuru arasında pozitif yönlü bir ilişkinin varlığına dikkatleri çekmiştir.

Branson (1983)'un geliştirdiği portföy dengesi yaklaşımında ise, hisse senedi fiyatları ile döviz kuru arasında negatif bir ilişki olduğu ve hisse senedi fiyatından döviz kuruna doğru bir nedensellik ilişkisinin geçerliliği ifade edilmektedir. Hisse senedi fiyatlarında meydana gelen bir artış, yatırımcının servetini artırırken, para talebinin yükselmesine neden olmaktadır. Para talebindeki artış bir taraftan yabancı paranın değer kaybetmesine, diğer taraftan da hisse senedi fiyatlarının yükselmesi ile yatırımcıların yabancı para cinsinden olan varlıklarını elden çıkarmalarına ve daha fazla hisse senedi alabilmek için ihtiyaç duydukları para talep düzeyinin yükselmesine neden olmaktadır. Para talebinin artması faiz oranlarını yükseltmekte ve bu durumda daha fazla yabancı yatırımcı yurtiçine çekilebilmektedir. Böylece para talebinde meydana gelen artış yabancı paranın değerinin düşmesine yol açmaktadır (Abdalla ve Murinde, 1997: 25; Smyth ve Nandha, 2003: 699-700; Rahman ve Uddin, 2009: 167; Alagidede vd., 2010: 2; İşcan, 2011: 241)

İlgili teorilerin geçerliliğini tespit edebilmek amacıyla bu çalışmada, döviz kuru ve borsa endeksi arasındaki ilişkiler 12 ülke itibariyle 1997:07-2013:12 dönemi için dengesiz panel veri analizleri kullanılarak incelenecektir. Bu kapsam dahilinde çalışma beş bölümden oluşmaktadır. Literatür özetlerinin sunulduğu ikinci bölümü takiben, çalışmanın üçüncü bölümünde analizlere konu olan veri seti ve model tanitılacaktır. Uygulama bulgularının 
açıklandığı dördüncü bölümün ardından çalışma, genel bir değerlendirmenin yapıldığı sonuç bölümüyle sona erdirilecektir.

\section{LITERATÜR ÖZETI}

Ekonomi ve finans literatüründe borsa hacmi ve döviz kuru arasındaki ilişkileri etkileyen mikro ve makroekonomik belirleyicilerin ön plana çıkarılması bağlamında yapılmış çok sayıda uygulamalı çalışma mevcuttur. Portföy teorisi ile geleneksel teorinin geçerliliklerini de irdeleyen bu çalışmalar, analiz sonuçlarına bağlı olarak borsa endekslerinin döviz kuru değişimine nasıl tepkide bulunabileceğini ve böylece optimum politika yapım sürecinin ne olması gerektiğini ortaya koymaya çalışmışlardır.

Granger vd. (2000), dokuz Asya ülkesinde 1986:01-1998:06 döneminde hisse senedi fiyatları ile döviz kuru arasındaki ilişkiyi zaman serisi analizleri yardımıyla incelemişlerdir. Güney Kore'de döviz kurlarının hisse senedi fiyatlarını etkilediğini gösteren analiz sonuçları; Malezya, Singapur, Tayland ve Tayvan'da ilgili değişkenler arasında çift yönlü nedensellik ilişkisinin varlığını kanıtlamıştır. Ancak benzer sonuçların Endonezya ve Japonya geçerli olmadığı da savunulmuştur.

Ayvaz (2006), hisse senetleri piyasası ve döviz kuru arasındaki ilişkiyi 1991:012004:12 dönemi için zaman serisi analizlerini kullanarak incelemiştir. Döviz kuru ile İMKB100 endeksi, mali sektör endeksi ve sanayi sektör endeksi arasında uzun dönemde istikrarlı bir ilişki olduğu tespit edilmiştir. Fakat döviz kuru ile hizmet sektör endeksi arasında ilişki bulunamamıştır. Ayrıca, döviz kuru ile hisse senetleri fiyat endeksi arasında iki yönlü nedensellik ilişkisi olduğu da tespit edilmiştir.

Yau ve Nieh (2006), Tayvan ve Japonya'da 1991:01-2005:07 döneminde hisse senedi fiyatları ve döviz kuru arasındaki kısa ve uzun dönemde ilişkileri araştırdıkları çalışmalarında, kısa dönemde iki ülke hisse senedi fiyatlarının birbirlerini etkilediğini ve böylece portföy yaklaşımının desteklendiğini belirtmişler, uzun dönemde ise geleneksel teorinin geçerli olduğu sonucuna varmışlardır. Ayrıca, döviz kuru ile hisse senedi fiyatları arasında uzun dönemli ilişkilerin söz konusu olmadığı da belirtilmiştir.

Erbaykal ve Okuyan (2007), 13 gelişmekte olan ülkede döviz kuru ve hisse senedi fiyatları arasındaki ilişkiyi panel veri analizlerini kullanılarak incelemişler ve 6 ülkede uzun dönemde değişkenler arasında negatif bir ilişki tespit etmişlerdir. Hisse senedi fiyatları ile döviz kuru arasında Brezilya, Güney Kore ve Malezya'da çift yönlü; Endonezya, Filipinler, Macaristan, Meksika ve Tayland'da ise hisse senedi fiyatlarından döviz kuruna doğru bir nedensellik ilişkisi tespit edilmiştir. Çek Cumhuriyeti, Çin, Hindistan, Şili ve Türkiye'de ise bu değişkenler arasında bir nedensellik ilişkisine rastlanmamıştır.

Özmen (2007), Türkiye için hisse senedi fiyatları ile döviz kurları arasındaki ilişkinin varlığını farklı döviz kuru rejimleri altında 1989-2006 dönemi günlük verilerini kullanarak incelemiştir. Birim kök test sonuçları her iki değişkenin de seviyede durağan olmadığını göstermiştir. Johansen eşbütünleşme test sonuçları, 2000 yılının analiz dışında bırakıldığı alt 
dönem sonuçları haricinde, değişkenler arasında uzun dönem ilişkinin varlığını göstermiştir. Toda-Yamamoto nedensellik test sonuçları ise, 1989-1994 ve 1994-1999 dönemleri dişında, değişkenler arasında çift yönlü bir nedenselliğin varlığı ortaya koymuştur. Kriz öncesi ve 2000 yılı analiz dışında bırakıldığında ise, değişkenler arasında tek yönlü bir nedensellik ilişkisinin varlığ 1 ifade edilmiştir.

Aslanoğlu (2008), 1999-2003 döneminde İMKB-100 endeksi ile emisyon hacmi, döviz kuru ve faiz oranları arasındaki ilişkiyi zaman serisi analizleri yardımıyla incelemiştir. Elde edilen bulgulara göre, İMKB-100 Endeksi ile emisyon hacmi arasında güçlü bir ilişki tespit edilmiştir. Endeks üzerinde etkili olan diğer değişkenler ise sırasıyla faiz oranları ve döviz kurları olmuştur. Döviz kurunun ilişki katsayısı düşük olsa da, İMKB-100 Endeksi üzerinde bir etkiye sahip olduğu tespit edilmiştir.

Avustralya ekonomisini dikkate alarak hisse senedi fiyatı ve döviz kuru arasındaki ilişkiyi 2003-2006 dönemi günlük verileri itibariyle zaman serisi analizlerini kullanarak inceleyen Richards ve Simpson (2009), ilgili değişkenler arasında uzun dönemli ilişkilerin varlığını ortaya koymuşlardır. İlaveten analiz sonuçları, hisse senedi fiyatlarından döviz kuruna doğru tek yönlü bir nedensellik bağının geçerli olduğunu da yansıtmıştır.

Alagidede vd. (2010), beş gelişmiş ülke için 1992:01-2005:12 döneminde hisse senedi piyasası ile döviz kuru arasındaki nedensellik ilişkisini zaman serisi analizleri yardımıyla incelemişlerdir. Değişkenler arasında uzun dönemli bir ilişki elde edemeyen yazarlar; Kanada, İsviçre ve İngiltere'de döviz kurundan hisse senedi fiyatlarına doğru güçlü bir tek yönlü nedensellik bağı bulmalarına karşın, hisse senedi fiyatlarından döviz kuruna doğru nedensellik ilişkisi sadece zayıf formda İsviçre ve Japonya için elde edilebilmiştir.

Doğukanlı vd. (2010), 1999:01-2009:06 dönemi için zaman serisi analizleri yardımıyla yapmış oldukları çalışmalarında İMKB'deki ana sektör ve alt sektör hisse senedi endekslerinin dolar ve euro para birimleri açısından döviz kuru duyarlılıklarını ortaya koymayı amaçlamışlardır. Sektörler ile döviz kurları arasında eşbütünleşme ilişkisinin varlığını gösteren Johansen eşbütünleşme testinin yanı sıra, sektörler arasında döviz kuru duyarlılıklarının farklılık gösterdiği tespit edilmiştir. Her iki para birimi açısından hizmetler sektörünün çok yüksek duyarlılık gösterdiği, mali sektörün duyarlılığının ise çok düşük olduğu ortaya konmuştur.

Batori vd. (2010), bazı AB üyesi ülkelerde 1999-2009 dönemi günlük verileri kullanarak hisse senedi endeksi ile döviz kuru arasında nedensellik ilişkisini zaman serisi analizleri kapsamında incelemişlerdir. Çek Cumhuriyeti, Macaristan ve Polonya'da değişkenler arasında çift yönlü nedensellik ilişkisi olduğu bulunmuştur. Danimarka'da döviz kurundan hisse senedi piyasasına doğru tek yönlü bir ilişki tespit edilirken, Romanya ve İsviçre için hisse senedi piyasasından döviz kuruna doğru tek yönlü ilişki tespit edilmiştir. İngiltere'de ise değişkenler arasında bir sebep-sonuç bağının söz konusu olmadığ görülmüştür. 
Yücel ve Özmen (2010), 1989-2009 döneminde faiz oran1, döviz kuru ve borsa endeksi değişkenlerinin iliş̧isini zaman serisi analizleri yardımıyla araştırmışlardır. Çalışma sonucunda, değişkenler arasında uzun dönemli ilişkinin varlığı ve borsa endeksi ile döviz kuru arasında çift yönlü bir nedensellik ilişkisi tespit edilmiştir.

Elmas ve Esen (2011); Türkiye, Almanya, Fransa, Hollanda, Rusya ve Hindistan'da yerel hisse senedi piyasa endeksleri ile döviz kuru arasındaki ilişkileri 1999:01-2010:03 dönemi için zaman serisi analizleri yardımıyla araştırmışlardır. Engle-Granger eş-bütünleşme testinde 1 ülke için ve Johansen eş-bütünleşme testinde ise 2 ülke için uzun dönemli bir ilişki tespit edilmiştir. Granger nedensellik testlerinde ise, 6 ülkenin her birinde değişken çiftleri arasında tek yönlü bir nedensellik ilişkisi tespit edilmiştir. Bu nedensellik ilişkisi 4 ülkede döviz kurundan piyasa endeksine doğru iken, 2 ülkede ise piyasa endeksinden döviz kuruna doğrudur. Bu sonuçlar; hisse senedi fiyatları ile döviz kuru arasında 4 ülkede "Geleneksel Yaklaşım"ın geçerli olduğunu desteklerken, 2 ülkede ise "Portföy Yaklaşımı"nın geçerli olduğunu desteklemektedir.

İşcan (2011), 2001:12-2009:12 dönemi itibariyle Türkiye ekonomisinde dolar ve euro kurları ile hisse senedi piyasası arasındaki etkileşimi zaman serisi analizlerini kullanarak araştırmıştır. Elde edilen sonuçlar, değişkenler arasında uzun dönemli bir ilişkinin varlığını göstermiş ve portföy yaklaşımının geçerliliği konusunda güçlü kanıtlar ortaya koymuştur. Granger nedensellik testi ise hisse senedi fiyatlarından döviz kuruna doğru tek yönlü bir sebep-sonuç bağı olduğunu yansıtmıştır.

Savaş ve Can (2011), İMKB'de işlem gören hisse senedi fiyatları ile Euro-Dolar Paritesi ve Reel Efektif Döviz Kuru Endeksi arasındaki ilişkiyi 2000:01-2009:07 dönemi itibariyle zaman serisi analizlerini kullanarak incelenmiştir. Çalışma sonucunda, Euro-Dolar Paritesi ve Reel Efektif Döviz Kuru Endeksi'nin İMKB-100 Endeksi'ni \%77,5 oranında açıkladığı ve pozitif yönde etkilediği tespit edilmiştir. Çalışmada ayrıca, IMKB-100 Endeksi'nden Euro-Dolar Paritesi ve Reel Efektif Döviz Kuru Endeksi'ne doğru bir nedensellik tespit edilmiştir.

Ayaydın ve Dağl1 (2012), 1994-2009 y1lı itibariyle 22 gelişen piyasa ekonomisi için hisse senedi getirisi ile makroekonomik değişkenler arasındaki ilişkiyi panel veri analizleri yardımıyla inceledikleri çalışmalarında, hisse senedi getirisinin döviz kurundan negatif yönlü olarak etkilendiğini saptamışlardır.

Tokat (2013); altın, döviz ve hisse senedi piyasalarında oynaklık etkileşimi mekanizmasını çok değişkenli GARCH modeli ile incelemiştir. 2000:01-2012:06 dönemini kapsayan çalı̧̧manın değişkenleri gram altın fiyatı, ABD dolar kuru ve IMKB-100 endeksi getirileridir. İlaveten çalışmada, Türkiye'deki hisse senedi piyasasının global altın ve dolar piyasası ile olan oynaklık etkileşimi ayrı bir sistemde incelenmiş̧tir. Çalışma sonucunda tüm parametrelerin kendi geçmiş şoklarından etkilendiği gözlemlenmiştir. Bunun yanında, USD/TL piyasasındaki şokların ve oynaklığın gram altın piyasası üzerinde etkisi olduğu 
görülmüştür. IMKB-100 endeksinin ise incelemeye konu olan global yatırım araçlarından bağımsız bir oynaklık seyri izlediği görülmüştür.

Şahin ve Sekmen (2013), 1986:05-2012:02 döneminde reel döviz kuru belirsizliği ile borsa getirisi arasındaki ilişkiyi ARCH/GARCH modellerini kullanarak incelemişlerdir. Elde edilen bulgular, döviz kuru belirsizliklerinin İMKB'de faaliyet gösteren şirketlerin getirisi üzerinde negatif yönlü anlamlı bir etkisinin olduğunu göstermiştir.

Tsagkanos ve Siriopoulos (2013), AB üyesi ülkeler ile ABD'de hisse senedi fiyatı ve döviz kuru arasındaki ilişkiyi 2008-2012 dönemi için günlük verileri kullanarak incelemişlerdir. AB üyesi ülkeler için euro-dolar kuru ile EUROTOP-300 endeksi ve ABD için euro-dolar kuru ile Dow Jones endeksi arasındaki ilişkiyi analiz eden çalışma bulguları, ABD'de kısa dönemde ve AB üyesi ülkelerde ise hisse senedi fiyatlarından döviz kuruna doğru hareket eden anlamlı bir ilişkinin varlığını göstermiştir.

Büberkökü (2013), altı gelişmiş ve üç gelişmekte olan ülkede döviz kuru ve hisse senedi fiyatları arasındaki ilişkiyi zaman serisi analizleri yardımıyla incelemiştir. Analiz sonuçları, Kanada ve İsviçre'de hisse senedi fiyatlarından döviz kuruna doğru tek yönlü nedensellik ilişkisinin geçerli olduğunu; ancak Japonya, Almanya, İngiltere ve Avustralya'da ise herhangi bir nedensellik ilişkisinin söz konusu olmadığını göstermiştir. Ayrıca, Singapur ve Güney Kore'de döviz kurundan hisse senedi fiyatlarına doğru tek yönlü nedensellik ilişkisinin varlığı kanıtlanmış, Türkiye'de ise hisse senedi fiyatlarından döviz kuruna doğru tek yönlü nedensellik ilişkisi bulunmuştur. Ayrıca, Singapur hariç olmak üzere ilgili değişkenler arasında uzun dönemli bir ilişki olmadığı görülmüştür.

Şentürk ve Dücan (2014), 1997:01-2013:05 döneminde faiz oranı ve döviz kuru dinamiklerinin borsa getirisi üzerindeki etkilerini VAR analizi yardımıyla inceledikleri çalışmalarında, faiz oranı ve döviz kuru yükseldikçe, borsa endeksinin getirisinin azaldığını tespit etmişlerdir. İlaveten, döviz kurundan borsa getirisine ve faiz oranından da döviz kuruna doğru tek yönlü nedensellik ilişkisinin söz konusu olduğu da ifade edilmiştir.

Caporale vd. (2014), beş gelişmiş ülke ve euro alanı itibariyle 2003-2011 döneminde borsa fiyatları ve döviz kuru arasındaki ilişkiyi iki değişkenli VAR-GARCH analizi yardımıyla incelemişlerdir. Analiz sonuçları, ABD ve İngiltere'de hisse senedi getirilerinden döviz kuruna doğru tek yönlü ve euro bölgesi ile İsviçre'de ise çift yönlü nedensellik ilişkisinin geçerli olduğunu göstermiştir. Kanada'da da ise bu nedensellik ilişkisinin döviz kurundan hisse senedi getirilerine doğru olduğu saptanmıştır.

Sevinç (2014), 2003:01-2013:03 dönemini kapsayan çalışmasında, makroekonomik değişkenlerin BIST-30 endeksinde işlem gören hisse senedi getirileri üzerindeki etkilerini Arbitraj Fiyatlama Modeli yardımıyla incelemiştir. Analiz sonuçları, makroekonomik değişkenlerin hisse senedi getirileri üzerindeki etkilerinin anlamlı olduğunu göstermiş ve hisse senedi getirilerinin Arbitraj Fiyatlama Modeli ile belirlenebileceğini ortaya koymuştur. Ayrıca, hisse senedi getirisi ile döviz kuru arasında beklenin tersine pozitif bir ilişki olduğu da görülmüştür. 
Yıldız (2014), 2001:03-2013:06 dönemi için BIST-100 pay endeksi ile faiz oranı, döviz kuru ve altın fiyat değişkenlerinin aralarındaki ilişkiyi zaman serisi analizlerini kullanarak incelemiştir. Çalışmada, pay senedi endeksi ile faiz oranı arasında negatif ilişki bulunmuştur. Ancak bu etkinin, gecikme değeri arttıkça azaldığını yani döviz kurunun kısa dönemde endekse karşı alternatif bir yatırım aracı olabileceği, fakat uzun vadede bu özelliğini kaybedeceği belirtilmiştir. Pay senedi endeksiyle döviz kuru arasındaki analiz sonuçları da döviz kurunun endeks üzerinde negatif bir etkisi olduğunu ortaya koymuştur.

Güngör ve Yerdelen-Kaygın (2015), Dinamik Panel Veri Analizleri yardımıyla BİST'de işlem gören 57 şirketin hisse senedi fiyatı ile mikro ve makroekonomik faktörler arasındaki ilişkiyi 2005-2011 dönemi itibariyle belirlemeye çalışmışlardır. Analiz sonuçları, modelde mikroekonomik faktörler olarak kullanılan, finansal oranlar ile hisse senedi fiyatları arasında anlamlı bir ilişki olduğunu göstermiştir. Başka bir ifade ile finansal oranların hisse senedi fiyatının tahmin edilmesinde kullanılabileceği sonucuna varılmıştır. Ayrıca, incelenen dönemde makroekonomik faktörlerden döviz kuru, para arzı, petrol fiyatları ve sanayi üretim endeksi ile hisse senedi fiyatı arasında pozitif yönlü bir ilişki bulunmuştur. Enflasyon oranı, faiz oranı, GSYİH, altın fiyatları ve dış ticaret dengesi ile hisse senedi fiyatı arasında ise negatif yönlü bir ilişki saptanmıştır.

\section{YÖNTEM VE VERILER}

Bu çalışmada, döviz kurlarının borsa endeksi üzerindeki etkilerini 12 ülke ${ }^{1}$ itibariyle 1997:07-2013:12 dönemi için inceleyebilmek amacıyla dengesiz panel veri analizlerinden yararlanılmıştır. İlgili dönemin dikkate alınmasının temel nedeni, verilere ulaşabilme imkanından kaynaklanmıştır. Döviz kurları, modellerde dikkate alınan ülkelerin ulusal paralarının Amerikan doları bazında dolaylı kotasyonunu ifade edecek şekilde oluşturulmuş ve böylece dolar bazında tüm ülkeler için ortak bir para birimi üzerinden değerlendirme yapılarak sapmalı tahmin sonuçlarının çıkması engellenmeye çalışılmıştır. Borsa endeksi ise, ilgili ülke borsalarının kapanış fiyatlarına göre oluşturulmuş endeks değerleri şeklinde dikkate alınmıştır. Temel iki değişkene ilaveten, döviz kurlarını doğrudan etkileme gücüne sahip olan tüketici fiyatları bazında enflasyon oranları ve on yıl vadeli devlet tahvillerine konu olan faiz oranları da kontrol değişkenleri olarak analizlere dahil edilmiştir. İlgili kontrol değişkenleri yardımıyla enflasyon ile faiz oranlarının döviz kurları ve bu noktadan hareketle de döviz kurlarının borsa endeksi üzerindeki etkileri, analizlerin sağlamlılığı (robustness) bağlamında irdelenmeye çalışılmıştır. Kullanılan değişkenlere ilişkin veriler EconStats, Türkiye Cumhuriyet Merkez Bankası (TCMB), Ekonomik İşbirliği ve Kalkınma Organizasyonu (OECD) ve Amerikan Merkez Bankası (FED)'nın resmi internet sitelerinden elde edilmiştir. Tablo 1, modelde kullanılan değişkenler ile ilgili temel bilgileri sunmaktadır.

\footnotetext{
${ }^{1}$ Söz konusu ülkeler: Türkiye, Avustralya, Kanada, Danimarka, Japonya, İsviçre, İngiltere, Almanya, Fransa, Finlandiya, Belçika, Avusturya.
} 
Tablo 1: Değişkenlere İlişkin Temel Bilgiler

\begin{tabular}{|c|c|c|c|c|c|}
\hline $\begin{array}{c}\text { Veri } \\
\text { Tanımı } \\
\end{array}$ & Kisaltma & $\begin{array}{c}\text { Veri } \\
\text { Kapsamı } \\
\end{array}$ & Birim & $\begin{array}{l}\text { Beklenen } \\
\text { İşaret }\end{array}$ & Kaynak \\
\hline Döviz Kurları & ER & $\begin{array}{l}\text { Ülkelerin Ulusal Paralarının } \\
\text { Amerikan Doları Bazında Dolaylı } \\
\text { Kotasyonu }\end{array}$ & USD \$ & - & $\begin{array}{l}\text { TCMB } \\
\text { FED }\end{array}$ \\
\hline Borsa Endeksi & SM & $\begin{array}{l}\text { Ülke Borsalarının Kapanış } \\
\text { Fiyatlarına Göre Oluşturulmuş } \\
\text { Endeks Değeri }\end{array}$ & Endeks & $\begin{array}{l}\text { Bağımlı } \\
\text { Değişken }\end{array}$ & EconStats \\
\hline Enflasyon Oranı & PL & $\begin{array}{lcc}\text { Tüketici } & \text { Fiyatları } & \text { Bazında } \\
\text { Enflasyon Oranları } & \\
\end{array}$ & $\%$ & $+/-$ & OECD \\
\hline Faiz Oranı & IR & Devlet Tahvili Faiz Oranları & $\%$ & + & OECD \\
\hline
\end{tabular}

Söz konusu değişkenler dikkate alındığında oluşturulan temel model kalıbı,

$$
S M_{i t}=\beta_{0}+\beta_{1} E R_{i t}+\left(\beta_{2} \text { KONTROL }_{i t}\right)+\varepsilon_{i t}
$$

olarak ifade edilebilir. (1) numaralı regresyon denkleminde yer alan $\beta_{0}$ parametresi, sabit terimi; $\beta_{1}$ terimi ve $\beta_{2}$ parametreleri, eğim katsayılarını; KONTROL $L_{i t}$ değişkeni, enflasyon ile faiz oranını ve $\varepsilon_{i t}$ ise beyaz gürültü hata terimini göstermektedir.

Ekonomik bir ilişkinin belirlenmesinde model kapsamındaki diğer değişkenlerle ilişkili olabilen ve gözlenemeyen bireysel özel etkileri kontrol etme isteğini yansıtan panel veri analizleri, 1980'li yıllardan itibaren artan bir ilgi görmektedir (Hausman ve Taylor, 1981: 1377). Panel veri analizinde birden fazla yatay kesit objesinin analiz dönemindeki gözlemleri kullanılarak regresyon yapılmakta ve bu nedenle de zaman serisi ile yatay kesit gözlemlerinin bir arada kullanılmasına izin verilmektedir. Tipik bir panel veri analizinde bağımlı değişken için $N$ sayıda bireyin $T$ dönemlik zaman serisi verileri kullanılarak analiz yapılmaktadır. $\beta_{\text {nit }}$ katsayı, $Y_{i t}$ bağımlı değişken ve $X_{n i t}$ ise bağımsız değişkenleri temsil etmek üzere genel anlamda panel veri denklemi aşağıdaki (2) numaralı eşitlik ile ifade edilmektedir: (Kaya ve Y1lmaz, 2006: 69)

$$
Y_{i t}=\beta_{1 i t}+\beta_{2 i t} X_{2 i t}+\beta_{3 i t} X_{3 i t}+\varepsilon_{i t} \quad t=1 \ldots T \text { ve } i=1 \ldots N
$$

Panel veri analizlerinde değişkenler arasındaki uzun dönemli ya da eşbütünleşik ilişkiler tespit edilebilmekte ve bu analizler için genellikle Pedroni ve Kao eşbütünleşme testlerinden yararlanılmaktadır. Pedroni (1999) tarafından geliştirilen eşbütünleşme testi, (3) numaralı panel regresyonundan hareketle ifade edilmektedir:

$$
y_{i t}=\alpha_{i t}+\delta_{i t} t+X_{i t} \beta_{i}+e_{i t}
$$

(3) numaralı eşitlikte yer alan $y_{i t}$ ve $X_{i t}$ sırasıyla $\left(N^{*} T\right) x 1$ ve $\left(N^{*} T\right) x m$ boyutundaki gözlemlenebilen değişkenleri, $\delta_{i t}$ ise trend değişkenine $(t)$ ilişkin katsayıyı vurgulamaktadır. $\mathrm{Bu}$ test, panel serilerinde eşbütünleşik bir ilişkinin olmadığını sınayan sıfır hipotezinin asimptotik ve sonlu gözlem özellikleri üzerine inşa edilmiştir. Hem uzun dönem eşbütünleşik vektörlerinde ve hem de dinamik modellerde panel seriyi oluşturan bireysel kesitler 
arasındaki heterojenliği ölçmeye olanak tanıyan bu eşbütünleşme analizi, iki test grubundan oluşmaktadır. İlk grubu oluşturan testler, boyutlar-içi yaklaşım üzerine temellendirilmiş olup; panel $v$-istatistiği, panel $\rho$-istatistiği, panel PP-istatistiği ve panel ADF-istatistiği olmak üzere dört testten oluşmaktadır. Bu istatistikler, tahmin edilen kalıntı serileri üzerindeki birim kök testleri için farklı yatay kesit birimleri arasında otoregresif katsayıları birleştirmektedir. İkinci grubu oluşturan testler ise boyutlar-arası yaklaşım üzerine inşa edilmiştir ki, toplamda üç testten meydana gelmektedirler. Bunlar; grup $\rho$-istatistiği, grup PP-istatistiği ve grup ADF-istatistiğidir. ${ }^{2}$

Pedroni (1999) testinin aksine, kesikli ve homojen katsayılar özelinde bir sinamanın söz konusu olduğu Kao (1999) eşbütünleşme testi ise, (4) numaralı panel regresyon modeline dayanmaktadır:

$$
y_{i t}=x_{i t}^{\prime} \beta+z_{i t}^{\prime} \gamma+\varepsilon_{i t}
$$

(4) numaralı eşitlikte $y_{i t}$ ve $x_{i t}$ 'nin $I(1)$ seviyesinde durağan oldukları ve eşbütünleşik bir ilişkinin gerçekleşmediği varsayılmaktadır. $\beta$, ilgili değişkene ait katsayıdır. “'” işaretli değişkenler, ilgili değişkenin türevinin alındığını yansıtmaktadır. $z_{i t}=\left\{\mu_{i}\right\}$ gibi bir eşitliği savunan Kao (1999), $\varepsilon_{i t}$ serisi için yapilacak DF ve ADF birim kök testlerinden hareketle seriler arasındaki eşbütünleşme ilişkisini araştırmıştır. DF serisinin, $\hat{\varepsilon}_{i t}=\rho \hat{\varepsilon}_{i, t-1}+v_{i t}$ ve ADF serisinin ise $\hat{\varepsilon}_{i t}=\rho \hat{\varepsilon}_{i, t-1}+\sum_{j=1}^{p} \varphi_{j} \Delta \hat{\varepsilon}_{i, t-j}+v_{i t p}$ eşitlikleri yardımıyla hesaplandığ 1 kalıplarda, $\hat{\varepsilon}_{i t}=\tilde{y}_{\hat{t} t}-\tilde{x}_{i t} \hat{\beta}$ ve $\tilde{y}=y_{i t}-\bar{y}_{i}$ olmaktadır. $\rho$ ve $\varphi$, değişkenlere ait katsayıları, $\Delta$ ise fark operatörünü yansıtmaktadır. Bu kalıplardan hareketle $\rho$ ve $t$ istatistiklerinin EKK tahminleri,

$$
\hat{\rho}=\frac{\sum_{i=1}^{N} \sum_{t=2}^{T} \hat{\varepsilon}_{i t} \hat{\varepsilon}_{i, t-1}}{\sum_{i=1}^{N} \sum_{t=2}^{T} \hat{\varepsilon}_{i t}^{2}} \text { ve } t_{\rho}=\frac{(\hat{\rho}-1) \sqrt{\sum_{i=1}^{N} \sum_{t=2}^{T} \hat{\varepsilon}_{i, t-1}^{2}}}{S_{e}}
$$

denklemleri yardımıyla hesaplanmaktadır. Kao (1999) tarafindan ortaya atılan eşbütünleşme analizi, seriler arasında eşbütünleşik bir ilişskinin olmadığının varsayıldığı sıfır hipotezini sınamaya çalışmakta ve beş farklı istatistik hesaplamasına dayanmaktadır. ${ }^{3}$

Eşbütünleşme analizlerini takiben, değişkenler arasındaki sebep-sonuç ilişkileri literatüre ilk kez Granger $(1964,1969)$ tarafindan kazandırılan ve daha sonra ise Hamilton (1994) tarafından geliştirilen nedensellik analizleri yardımıyla incelenmiştir. Granger nedenselliğinde $X$ ve $Y$ gibi iki değişken arasındaki ilişsinin yönü araştırılır. Eğer mevcut $Y$ değeri, $X$ değişkenin şimdiki değerinden çok, geçmiş dönem değerleri ile daha iyi tahmin edilebiliyorsa, $X$ değişkeninden $Y$ değişkenine doğru bir Granger nedenselliğinden söz

\footnotetext{
${ }^{2}$ Bu test istatistikleri hakkında daha fazla bilgi için bkz. Pedroni (1999).

${ }^{3} \mathrm{Bu}$ test istatistikleri hakkında daha fazla bilgi için bkz. Kao (1999).
} 
edilebilir (Charemza ve Deadman, 1993: 190). İki değişken arasında "sebep olma ilişkisi”" araştırılırken (6) ve (7) numaralı kalıplar uygulanır: (Kutlar, 2007: 267)

$$
\begin{aligned}
& Y_{i t}=\sum_{i=1}^{n} \alpha_{i t} Y_{i, t-k}+\sum_{i=1}^{n} \beta_{i t} X_{i, t-k}+E C_{i t-1}+u_{1 i t} \\
& X_{i t}=\sum_{i=1}^{n} \alpha_{i t} X_{i, t-k}+\sum_{i=1}^{n} \beta_{i t} Y_{i, t-k}+E C_{i t-1}+u_{2 i t}
\end{aligned}
$$

Burada, $u_{1 i, t}$ ve $u_{2 i, t}$ hata terimlerinin ilişkisiz oldukları varsayılmaktadır. $\alpha$ ve $\beta$, ilgili değişkenlere ait katsayıları, $E C$ ise hata düzeltme parametresini sunmaktadır. Böylece, (6) ve (7) numaralı denklemler değişkenlerin geçmiş değerlerine bağlı olduğu kadar, kendi geçmiş değerlerinin de bir fonksiyonudur. Granger nedenselliğinde; $Y_{i t}$ ile $X_{i t}$ arasında tek ve çift yönlü bir nedensellik ilişkisi olabileceği gibi, değişkenler arasında herhangi bir nedensellik ilişkisinin söz konusu olmadığı durum da ortaya çıkabilir. Değişkenler arasında uzun dönemli ilişkilerin geçerli olması durumunda eşbütünleşme denklemlerinden elde edilen hata kalıntıları nedensellik ilişkilerinin araştırıldığı regresyonlara dahil edilmekte ve $E C$ olarak adlandırılmaktadır.

\section{UYGULAMA BULGULARI}

Çalışmada, veri seti dikkate alındığında model bazında kullanılan değişkenlerin maksimum 17 yıla ait gözlemler içerdiği görülmektedir. Yani, $N=12$ ve $T=17$ 'dir. Bu özellikleri gösteren gerek ulusal ve gerekse uluslararası literatürde panel veri analizleri kapsamında birim kök testlerini kullanmaksızın sadece değişkenlerin gecikmeli değerlerini dikkate alarak model tahminlerini ortaya koyan çok sayıda çalışma mevcuttur. Bununla birlikte, bu çalışmada öncelikle değişkenlerin zaman serisi özellikleri incelenmiştir. Çünkü zaman serisi özellikleri incelenmeden tahmin edilen bir model Granger ve Newbold (1974)'un ifade ettiği gibi, gerçekte olmayan ilişkilerin varmış gibi görünmesi olarak ifade edilen sahte regresyonlara neden olabilmektedir. $\mathrm{Bu}$ nedenle, model çözümlemelerinde kullanılacak olan değişkenlerin durağan olup olmadıkları ve eğer durağan iseler hangi seviyede durağan oldukları çeşitli birim kök testleri ile belirlenmiştir. Durağanlaştırma işlemi ile birlikte hem sahte regresyon sorunu ortadan kalkmakta ve hem de değişkenlere ait deterministik özellikler belirlenmektedir (MacKinnon, 1991: 266-267). Dolayssiyla, literatürde yer alan ve panel veri analizlerini kullanan pek çok çalışmanın ampirik sırasını takip etmek yerine, ifade edilen öneminden dolayı bu çalışmada panel birim kök testlerine yer verilmiştir. Birim kökün varlığını test etmek için panel veri seti kullanıldığında yatay kesit bağımlılığının sınanması da önemli bir unsuru oluşturmaktadır. Panel veri setinde yatay kesit bağımlılığı reddedilirse 1 . nesil birim kök testlerinin kullanılması daha uygun olmakta, aksine yatay kesit bağımlılığının geçerli olduğu saptanırsa 2. nesil birim kök testlerinin kullanımı daha tutarlı sonuçların elde edilmesine olanak tanımaktadır (Çınar, 2010: 594; Yüce Akıncı vd., 2013: 88). Tablo 2, yatay kesit bağımlılığını ölçen çeşitli test sonuçlarını yansıtmaktadır. 
Tablo 2: Yatay Kesit Bağımlılı̆ğ Test Sonuçları

\begin{tabular}{lcc}
\hline \multicolumn{1}{c}{ Test } & Istatistik Değeri & Olasilık \\
\hline Breusch-Pagan $L M$ İstatistiği & 870.713 & 0.574 \\
Pearson $L M$ İstatistiği & 330.117 & 0.881 \\
Pearson $C D$ İstatistiği & 54.814 & 0.996 \\
Friedman $L M$ İstatistiği & $1324.794^{* * * *}$ & 0.000 \\
Frees $Q$ İstatistiği & $3.969^{* * *}$ & 0.000 \\
\hline \multicolumn{4}{c}{ Asimptotik Kritik Değerler } \\
\hline
\end{tabular}

Not: Asimptotik kritik değerler yalnızca Frees $Q$ İstatistiği için geçerlidir. ${ }^{*}{ }^{*}$ işareti, ilgili istatistik değerinin $\% 1$ önem düzeyinde anlamlı olduğunu göstermektedir.

Tablo 2'de sunulan ilk üç test istatistiği yatay kesit bağımlılığının olmadığını, son iki test ise yatay kesit birimleri arasında korelasyon ilişkilerinin olduğunu yansıtmaktadır. $\mathrm{Bu}$ doğrultuda, yatay kesit bağımlılığının olmadığını ve birim kökün varlığını tespit etmek için 1 . nesil birim kök testlerinin kullanılmasının daha uygun olacağını söylemek mümkündür.

Tablo 3, birinci nesil birim kök test bulgularını göstermektedir. Birim kök testi bulguları, altı farklı durağanlık testi için dikkate alınan değişkenlerin bir kısmının seviye ve bir kısmının da birinci fark değerlerinde durağan olduğunu göstermiştir. Bununla birlikte, istisnasız olarak birinci fark değerlerinde durağan olmalarından dolayı bütün değişkenlerin I(1) olduğu dikkate alınarak analizlere devam edilecektir.

Modelde dikkate alınan değişkenlerin birinci fark düzeyinde durağan olmalarından dolayı ilgili değişkenler arasındaki uzun dönemli ilişkilerin tespit edilebilmesi için Pedroni ve Kao eşbütünleşme testlerinden yararlanılmıştır. Bu amaç doğrultusunda hazırlanan Tablo 4, çoklu ilişkileri dikkate alan eşbütünleşme test sonuçlarını yansıtmaktadır.

Tablo 4'de gösterilen Pedroni ve Kao eşbütünleşme sonuçları, ilgili değişkenler arasında eşbütünleşik, yani uzun dönemli ilişkilerin geçerli olduğu sonucunu ortaya koymuştur. İlgili bulgu, değişkenlerin uzun dönem itibariyle birbirleri üzerinde makroekonomik bakımdan etkili olabileceği şeklinde yorumlanabilir. Uzun dönemli ilişkilerin elde edilmesi, değişkenler arasında en azından tek yönlü bir nedensellik ilişkisinin geçerli olmasının beklendiğini yansıtmaktadır. Analizlerin temel amacı, borsa değeri üzerinde döviz kurunun ve döviz kuruna yansıyarak borsa değerini belirleyen temel makroekonomik değişkenlerin etkilerini görebilmek olduğundan dolayı, kontrol değişkenlerinin birbirleri üzerindeki etkilerinden ziyade, döviz kuru ve kontrol değişkenlerinin borsa değeri üzerindeki nedensellik etkileri dikkate alınmıştır. Dolayısıyla Tablo 5, değişkenler arasındaki sebepsonuç ilişkilerini yansıtan Granger nedensellik analiz bulgularını göstermektedir. 
Tablo 3: Panel Birim Kök Testi Sonuçları

\begin{tabular}{|c|c|c|c|c|c|c|c|c|c|c|c|c|}
\hline \multirow[b]{2}{*}{ Değişken } & \multicolumn{4}{|c|}{ LLC $t$ İstatistiği } & \multicolumn{4}{|c|}{ Breitung $t$ İstatistiği } & \multicolumn{4}{|c|}{ IPS $W$ İstatistiği } \\
\hline & Seviye & $\begin{array}{c}\text { Birinci } \\
\text { Fark }\end{array}$ & $\begin{array}{l}\text { Kesit } \\
\text { Sayısı }\end{array}$ & $\begin{array}{c}\text { Gözlem } \\
\text { Sayısı }\end{array}$ & Seviye & $\begin{array}{c}\text { Birinci } \\
\text { Fark }\end{array}$ & $\begin{array}{l}\text { Kesit } \\
\text { Sayısı }\end{array}$ & $\begin{array}{c}\text { Gözlem } \\
\text { Sayısı }\end{array}$ & Seviye & $\begin{array}{c}\text { Birinci } \\
\text { Fark }\end{array}$ & $\begin{array}{l}\text { Kesit } \\
\text { Sayısı }\end{array}$ & $\begin{array}{c}\text { Gözlem } \\
\text { Sayısı }\end{array}$ \\
\hline SM & 1.734 & $-50.992^{* * * *}$ & 12 & 2225 & $-1.791^{* * *}$ & $-24.421^{* * * 4}$ & 12 & 2213 & 0.732 & $-43.597^{* * *}$ & 12 & 2225 \\
\hline ER & -0.630 & $-45.333^{* * *}$ & 12 & 2231 & $-3.128^{* * *}$ & $-25.268^{* * *}$ & 12 & 2219 & -1.003 & $-36.209^{* * *}$ & 12 & 2231 \\
\hline IR & $-3.346^{* * *}$ & $-42.722^{* * *}$ & 12 & 2176 & -0.289 & $-24.339^{* * *}$ & 12 & 2164 & $-5.036^{* * *}$ & $-36.387^{* * *}$ & 12 & 2176 \\
\hline PL & 4.792 & $-38.561^{* * *}$ & 12 & 2284 & -0.343 & $-7.383^{* * *}$ & 12 & 2272 & $-3.039^{* * *}$ & $-31.700^{* * *}$ & 12 & 2284 \\
\hline \multirow{2}{*}{ Değişken } & \multicolumn{4}{|c|}{ ADF-Fisher $\chi^{2}$ İstatistiği } & \multicolumn{4}{|c|}{ PP-Fisher $\chi^{2}$ İstatistiği } & \multicolumn{4}{|c|}{ Hadri $Z$ İstatistiği } \\
\hline & Seviye & $\begin{array}{l}\text { Birinci } \\
\text { Fark }\end{array}$ & $\begin{array}{l}\text { Kesit } \\
\text { Sayısı }\end{array}$ & $\begin{array}{c}\text { Gözlem } \\
\text { Sayısı }\end{array}$ & Seviye & $\begin{array}{c}\text { Birinci } \\
\text { Fark }\end{array}$ & $\begin{array}{l}\text { Kesit } \\
\text { Sayısı }\end{array}$ & $\begin{array}{c}\text { Gözlem } \\
\text { Sayısı }\end{array}$ & Seviye & $\begin{array}{l}\text { Birinci } \\
\text { Fark }\end{array}$ & $\begin{array}{l}\text { Kesit } \\
\text { Sayısı }\end{array}$ & $\begin{array}{c}\text { Gözlem } \\
\text { Sayısı }\end{array}$ \\
\hline SM & 15.823 & $998.550^{* * * *}$ & 12 & 2225 & 18.668 & $1008.96^{\text {**** }}$ & 12 & 2225 & 9.159 & $0.784^{* * 4}$ & 12 & 2225 \\
\hline ER & 25.145 & $819.500^{* * * *}$ & 12 & 2231 & 22.632 & $821.560^{* * * *}$ & 12 & 2232 & 14.628 & $0.452^{* * *}$ & 12 & 2225 \\
\hline IR & $67.514^{* * *}$ & $819.889^{* * * *}$ & 12 & 2176 & $59.614^{* * *}$ & $843.888^{* * * *}$ & 12 & 2179 & 0.886 & $0.684^{* *}$ & 12 & 2225 \\
\hline PL & $45.486^{* * *}$ & $697.243^{* * *}$ & 12 & 2284 & $53.631^{* * *}$ & $1063.11^{* * *}$ & 12 & 2352 & 14.468 & $0.553^{* *}$ & 12 & 2225 \\
\hline
\end{tabular}

Not: Fisher testleri için belirtilen istatistikler asimptotik $\chi^{2}$ dağılımı ve diğer test istatistikleri ise asimptotik normallik varsayımı dikkate alınarak hesaplanmıştır. ${ }^{* *}$ ve *** işaretleri ilgili değişkenin sırasıyla \%5 ve \%1 önem düzeyinde durağan olduğunu yansıtmaktadır. İstatistikler hesaplanırken optimum gecikme uzunluğunun belirlenmesinde SIC kriterinden yararlanılmıştır. Ayrıca; LLC, PP-Fisher ve Hadri istatistik değerleri hesaplanırken hem Barlett Kerneli ve hem de Newey-West bant genişlik kriterlerinden yararlanılmıştır. 
Tablo 4: Çoklu İlişkileri Dikkate Alan Pedroni ve Kao Eşbütünleşme Analiz Sonuçları

\begin{tabular}{|c|c|c|}
\hline \multicolumn{3}{|c|}{ Pedroni Eşbütünleşme Testi } \\
\hline Test & İstatistik Değeri & Olasılık Değeri \\
\hline \multicolumn{3}{|l|}{ Boyutlar-İçi Testler } \\
\hline Panel $v$ İstatistiği & -3.601 & 0.999 \\
\hline Panel rho İstatistiği & $-53.264^{* * *}$ & 0.000 \\
\hline Panel $P P$ İstatistiği & $-35.142^{* * *}$ & 0.000 \\
\hline Panel $A D F$ İstatistiği & $-34.995^{* * *}$ & 0.000 \\
\hline \multicolumn{3}{|l|}{ Boyutlar-Arası Testler } \\
\hline Grup rho İstatistiği & $-46.006^{* * *}$ & 0.000 \\
\hline Grup $P P$ İstatistiği & $-36.056^{* * * *}$ & 0.000 \\
\hline Grup $A D F$ İstatistiği & $-36.111^{* * *}$ & 0.000 \\
\hline \multicolumn{3}{|c|}{ Kao Eşbütünleşme Testi } \\
\hline $\begin{array}{r}\text { Test } \\
\end{array}$ & İstatistik Değeri & Olasilık Değeri \\
\hline Kao-ADF İstatistiği & $4.289^{* * * *}$ & 0.000 \\
\hline $\begin{array}{l}\text { Not: Eşbütünleşme ilişkis } \\
\text { bant genişlik kriterlerir } \\
\text { hesaplanmasında SIC krit } \\
\text { anlamlı olduklarını yansıtn }\end{array}$ & $\begin{array}{l}\text { için kullanilan he } \\
\text { r. Değişkenlere } \\
\text { işareti ilgili ista }\end{array}$ & $\begin{array}{l}\text { tt Kerneli ve } \mathrm{Ne} \\
\text { gecikme uzu } \\
\text { siyla \%1 önem }\end{array}$ \\
\hline
\end{tabular}

Tablo 5: Granger Nedensellik Analiz Sonuçları

\begin{tabular}{cccc}
\hline Değişken Çifti & Nedenselliğin Yönü & $\boldsymbol{F}$ İstatistiği (Olasılık) & $\boldsymbol{E C}_{t-\boldsymbol{I}}$ (Olasılık) \\
\hline$\Delta \mathrm{SM}(1)-\Delta \mathrm{ER}(5)$ & - & $1.078(0.369)$ & $-0.115(0.781)$ \\
$\Delta \mathrm{ER}(5)-\Delta \mathrm{SM}(1)$ & $\rightarrow$ & $1.978^{*}(0.075)$ & $-0.577^{*}(0.077)$ \\
\hline$\Delta \mathrm{SM}(1)-\Delta \mathrm{IR}(1)$ & - & $1.166(0.280)$ & $0.229(0.550)$ \\
$\Delta \mathrm{IR}(1)-\Delta \mathrm{SM}(1)$ & $\rightarrow$ & $14.903^{* * * *}(0.000)$ & $-0.754^{* * *}(0.006)$ \\
\hline$\Delta \mathrm{SM}(1)-\Delta \mathrm{PL}(1)$ & - & $0.604(0.437)$ & $0.196(0.665)$ \\
$\Delta \mathrm{PL}(1)-\Delta \mathrm{SM}(1)$ & $\rightarrow$ & $12.571^{* * * *}(0.000)$ & $-0.697^{* * * *}(0.003)$ \\
\hline
\end{tabular}

Not: $\Delta$ terimi, ilgili değişkene ait fark operatörünü belirtmektedir. Parantez içindeki değerler, maksimum sekiz gecikme uzunluğu üzerinden SIC kriterleri kullanılarak hesaplanan optimum gecikme uzunluklarını yansıtmaktadır. ${ }^{*}$ ve ${ }^{* * *}$ işaretleri ilgili istatistiklerin sırasıyla \%10 ve \%1 önem düzeyinde anlamlı olduğunu yansıtmaktadır. EC terimi, eşbütünleşme denklemlerinden elde edilen hata düzeltme mekanizmasını ifade etmektedir.

Modelde dikkate alınan değişkenler arasında uzun dönemli bir ilişki olduğundan dolayı, eşbütünleşme denklemlerinden elde edilen hata terimi nedensellik analizlerine dahil edilmiş ve $E C$ olarak adlandırılmıştır. Granger nedensellik analiz sonuçları, beklentileri karşılar nitelikte ilgili değişkenler arasında en azından tek yönlü olarak sebep-sonuç ilişskilerinin geçerli olduğunu göstermiştir. Ayrıca, aralarında nedensellik ilişkisi olan değişkenlerin hata düzeltme mekanizmalarına ait olan istatistiklerin negatif ve istatistiki bakımdan anlamlı olması, ilgili değişkenlerin kendi denge değerlerine yakınsayabileceklerini ve kısa dönemde ortaya çıkabilecek olan dengesizliklerin uzun önemde giderilebileceğini ortaya koymuştur. Bu kapsamda; döviz kuru, faiz ve enflasyon oranlarının borsa değerini etkileyen temel faktörler olduğunu söylemek mümkündür.

Çalışmanın bu aşamasında, (1) numaralı temel regresyon modeli tahmin edilmeye çalışılmıştır. Belirtilen model dahilinde öncelikle uygun panel veri modeline karar 
verilebilmesi amacıyla birim ve zaman etkileri belirlenmiş ve bu doğrultuda $F$ ve $L M$ testleri yapılmıştır. İlgili istatistiklere ait test sonuçları Tablo 6'da sunulmuştur.

Tablo 6: Birim ve Zaman Etkilerini Gösteren $F$ ve $L M$ Test Sonuçları

\begin{tabular}{|c|c|c|c|c|c|c|}
\hline Model & \multicolumn{2}{|c|}{$F$ Testi } & \multicolumn{2}{|c|}{$L M$ Testi } & Hausman Testi & Uygun Model \\
\hline \multirow{4}{*}{$\begin{array}{l}\Delta \mathrm{SM} \\
\Delta \mathrm{ER}\end{array}$} & Test & İstatistik & Test & İstatistik & \multirow{4}{*}{$\begin{array}{l}23.253 \\
(0.000)\end{array}$} & \multirow{4}{*}{$F_{\text {Birim-Zaman }}$} \\
\hline & $F_{\text {Birim }}$ & $2.659^{* * *}$ & $L M_{\text {Birim }}$ & $25.012^{* * * *}$ & & \\
\hline & $F_{\text {Zaman }}$ & $2.522^{* * *}$ & $L M_{\text {Zaman }}$ & $12.635^{*}$ & & \\
\hline & $F_{\text {Birim-Zaman }}$ & $2.525^{* * *}$ & LM Birim-Zaman & $18.114^{* *}$ & & \\
\hline Model & \multicolumn{2}{|c|}{$F$ Testi } & \multicolumn{2}{|c|}{$L M$ Testi } & Hausman Testi & Uygun Model \\
\hline \multirow{4}{*}{$\begin{array}{c}\Delta \mathrm{SM} \\
\Delta \mathrm{IR}\end{array}$} & Test & İstatistik & Test & İstatistik & \multirow{4}{*}{$\begin{array}{l}21.806 \\
(0.000)\end{array}$} & \multirow{4}{*}{$F_{\text {Birim-Zaman }}$} \\
\hline & $F_{\text {Birim }}$ & $2.087^{* *}$ & $L M_{\text {Birim }}$ & $22.003^{* * * *}$ & & \\
\hline & $F_{\text {Zaman }}$ & $2.648^{* * *}$ & $L M_{\text {Zaman }}$ & $16.996^{* * *}$ & & \\
\hline & $F_{\text {Birim-Zaman }}$ & $2.629^{* * *}$ & $L M_{\text {Birim-Zaman }}$ & $19.480^{* * *}$ & & \\
\hline Model & \multicolumn{2}{|c|}{$F$ Testi } & \multicolumn{2}{|c|}{$L M$ Testi } & Hausman Testi & Uygun Model \\
\hline \multirow{4}{*}{$\begin{array}{c}\Delta \mathrm{SM} \\
\Delta \mathrm{PL}\end{array}$} & Test & İstatistik & Test & İstatistik & \multirow{4}{*}{$\begin{array}{l}16.223 \\
(0.000)\end{array}$} & \multirow{4}{*}{$F_{\text {Birim-Zaman }}$} \\
\hline & $F_{\text {Birim }}$ & $2.849^{* * *}$ & $L M_{\text {Birim }}$ & $26.491^{* * * *}$ & & \\
\hline & $F_{\text {Zaman }}$ & $2.526^{* * *}$ & $L M_{\text {Zaman }}$ & $6.324^{*}$ & & \\
\hline & $F_{\text {Birim-Zaman }}$ & $2.537^{* * *}$ & LM $M_{\text {Birim-Zaman }}$ & $15.963^{* *}$ & & \\
\hline Model & \multicolumn{2}{|c|}{$F$ Testi } & \multicolumn{2}{|c|}{$L M$ Testi } & Hausman Testi & Uygun Model \\
\hline$\Delta \mathrm{SM}$ & Test & Istatistik & Test & İstatistik & \multirow{4}{*}{$\begin{array}{l}22.994 \\
(0.000)\end{array}$} & \multirow{4}{*}{$F_{\text {Birim-Zaman }}$} \\
\hline$\Delta \mathrm{ER}$ & $F_{\text {Birim }}$ & $1.873^{* *}$ & LM $M_{\text {Birim }}$ & $19.647^{*}$ & & \\
\hline$\Delta \mathrm{IR}$ & $F_{\text {Zaman }}$ & $2.610^{* * *}$ & $L M_{\text {Zaman }}$ & $25.814^{* * * *}$ & & \\
\hline$\Delta \mathrm{PL}$ & $F_{\text {Birim-Zaman }}$ & $2.579^{* * *}$ & $L_{\text {Birim-Zaman }}$ & $22.047^{* * *}$ & & \\
\hline
\end{tabular}

Not: $\Delta$ terimi, ilgili değişkene ait fark operatörünü belirtmektedir. Tabloda yer alan " ${ }^{* *}$ ve ${ }^{k * *}$ işaretleri ilgili test istatistiğinin sırasıyla $\% 10, \% 5$ ve $\% 1$ önem düzeyinde anlamlı olduğunu göstermektedir. Parantez içindeki değerler, Hausman test istatistiğine ait olasılık değerlerini yansıtmaktadır.

Birim ve zaman etkilerini gösteren F ve LM testi analiz sonuçları, dört ayrı regresyon modeli için benzer birim-zaman etkilerinin geçerli olduğunu göstermiştir. İlaveten, Hausman testi doğrultusunda her model için sabit etkili modelin daha tutarlı sonuçlar verdiği görülmektedir. Birim ve zaman etkilerinin tespit edilmesini takiben modelde dikkate alınan değişkenler arasındaki ilişkileri belirleyebilmek amacıyla sabit etkili modeller tahmin edilmiş ve analiz sonuçları Tablo 7'de sunulmuştur. 
Tablo 7: Model Tahmin Sonuçları

\begin{tabular}{|c|c|c|c|c|}
\hline \multicolumn{5}{|c|}{ Bağımlı Değişken: $\Delta \mathrm{SM}$} \\
\hline \multirow{2}{*}{$\begin{array}{l}\text { Bağımsız } \\
\text { Değișkenler }\end{array}$} & \multicolumn{4}{|c|}{ Regresyon Modelleri } \\
\hline & 1 & 2 & 3 & 4 \\
\hline Sabit (C) & $41.946^{* *}[0.041]$ & $32.659[0.105]$ & $43.015^{* *}[0.037]$ & $32.462[0.107]$ \\
\hline$\Delta \mathrm{SM}(-1)$ & $0.070^{* * * *}[0.001]$ & $0.077^{* * *}[0.000]$ & $0.072^{* * * *}[0.001]$ & $0.077^{* * * *}[0.000]$ \\
\hline$\Delta \mathrm{ER}$ & $-0.652^{*}[0.077]$ & $-0.710^{* *}[0.032]$ & $-1.220^{*}[0.091]$ & $-1.246^{* *}[0.048]$ \\
\hline$\Delta \mathrm{ER}(-1)$ & $3.611[0.372]$ & $5.728[0.314]$ & $2.898[0.366]$ & $2.557[0.336]$ \\
\hline$\Delta \mathrm{ER}(-2)$ & $5.347[0.839]$ & $0.453[0.985]$ & $5.276[0.841]$ & $0.352[0.989]$ \\
\hline$\Delta \mathrm{ER}(-3)$ & $-3.692[0.603]$ & $-1.961[0.456]$ & $-1.852[0.598]$ & $-1.694[0.486]$ \\
\hline$\Delta \mathrm{ER}(-4)$ & $2.090[0.323]$ & $2.130[0.305]$ & $2.096[0.323]$ & $2.467[0.281]$ \\
\hline$\Delta \mathrm{ER}(-5)$ & $-2.568[0.313]$ & $-2.654[0.295]$ & $-2.905[0.305]$ & $-2.809[0.292]$ \\
\hline$\Delta \mathrm{IR}$ & & $5.069^{* * * *}[0.000]$ & & $5.370^{* * * * *}[0.000]$ \\
\hline$\Delta \operatorname{IR}(-1)$ & & $4.938^{* * *}[0.000]$ & & $4.251^{* * * *}[0.000]$ \\
\hline$\Delta \mathrm{PL}$ & & & $2.001^{* * * *}[0.003]$ & $7.487^{*}[0.081]$ \\
\hline$\Delta \mathrm{PL}(-1)$ & & & $0.862[0.937]$ & $-1.575[0.910]$ \\
\hline $\mathrm{EC}(-1)$ & $-0.521^{*}[0.083]$ & $-0.556^{* *}[0.024]$ & $-0.548^{* * *}[0.033]$ & $-0.611^{* * * *}[0.005]$ \\
\hline Uygun Model & $\mathrm{FE}$ & $\mathrm{FE}$ & $\mathrm{FE}$ & $\mathrm{FE}$ \\
\hline Birim Etkisi & Evet & Evet & Evet & Evet \\
\hline Zaman Etkisi & Evet & Evet & Evet & Evet \\
\hline \multicolumn{5}{|c|}{ Modele İlişkin İstatistikler } \\
\hline$R^{2}$ & 0.408 & 0.532 & 0.508 & 0.534 \\
\hline$F$ İstatistiği & $2.473^{* * *}$ & $2.759^{* * * *}$ & $2.451^{* * * *}$ & $2.752^{* * * *}$ \\
\hline $\operatorname{Prob}(F)$ & 0.000 & 0.000 & 0.000 & 0.000 \\
\hline DW & 2.001 & 1.986 & 2.002 & 1.988 \\
\hline Kesit Sayısı & 12 & 12 & 12 & 12 \\
\hline Gözlem Sayısı & 2177 & 2131 & 2177 & 2131 \\
\hline
\end{tabular}


Tablo 7'de gösterilen model tahmin sonuçları, dört ayrı regresyon modeli için borsa endeks değerinin bir dönem gecikmeli değerinin borsa endeksi pozitif ve istatistiki bakımdan anlamlı olarak etkilediğini yansıtmıştır. Ayrıca, döviz kurunun cari değerinin borsa endeksi üzerindeki etkisinin beklentileri karşılar nitelikte negatif ve istatistiki bakımdan anlamlı olduğu da gözlenmiştir. Bununla birlikte, döviz kurunun gecikmeli değerlerinin borsa endeksi üzerinde anlamlı bir etkiye sahip olmaması, borsa endeks değerinin tahmin edilmesinde cari döviz kurunun baskın bir yapıda olduğuna işaret etmiştir. Modellere ilave edilen kontrol değişkenlerinin döviz kuru üzerinde etkin bir rol oynadığının görüldüğü analiz sonuçları, döviz kuru kanalından hareketle borsa endeksinin etkilendiğini göstermiştir. Faiz oranının cari ve bir dönem gecikmeli değerleri ile enflasyon oranının cari değerinin döviz kuru üzerinde baskı yaratan temel faktörler olduğunun belirlendiği analiz sonuçları, ifade edilen kontrol değişkenlerinin borsa endeksi üzerinde pozitif ve istatistiki bakımdan anlamlı etkiler yarattığını ortaya koymuştur. Dolayısıyla, borsa endeksinin başta döviz kuru olmak üzere, döviz kurunu çeşitli mekanizmalar yardımıyla etkileyen faiz ve enflasyon oranlarından etkilendiğini söylemek olasıdır. İlaveten, modellerin bir bütün olarak anlamlı olması, otokorelasyon problemini bünyesinde barındırmaması ve nispeten yüksek sayılabilen belirlilik katsayıları nedeniyle robust sonuçlar ortaya koyduğu belirtilebilir. Ayrıca, değişkenler arasında uzun dönemli ilişkiler elde edildiğinden dolayı regresyon modellerine dahil edilen hata düzeltme mekanizmasının (EC) beklentileri karşılar nitelikte negatif ve istatistiki bakımdan anlamlı olması, kısa dönemde ortaya çıkabilecek olan makroekonomik dengesizliklerin uzun dönemde giderilebileceğini göstermiştir.

\section{SONUÇ}

$\mathrm{Bu}$ çalışmada, döviz kurlarının borsa endeksi üzerindeki etkileri 12 ülke itibariyle 1997:07-2013:12 dönemi için dengesiz panel veri analizleri yardımıyla incelenmiştir. Ayrıca, döviz kurlarına yansıyarak borsa endeks değerine etki edebilecek olan enflasyon ve faiz oranı kontrol değişkenleri de modelleme süreçlerine katılmış ve robust sonuçlar elde edilmeye çalışılmıştır.

Panel veri analizleri kapsamında hangi birim kök testlerinin kullanılacağını belirleyebilmek için ilk olarak çeşitli yatay kesit bağımlılı̆g testleri uygulanmıştır. Analiz sonuçları, yatay kesit birimleri arasında korelasyon ilişkilerinin geçerli olmadığını ortaya koymuş ve bu doğrultuda birim kökün varlığını tespit etmek için 1. nesil birim kök testlerinin kullanılmasının daha uygun olacağı tespit edilmiştir. $\mathrm{Bu}$ amaç doğrultusunda yapılan altı farklı birim kök testi sonuçları, dikkate alınan değişkenlerin birinci fark düzeylerinde durağan olduğunu göstermiştir. Değişkenlere ait durağanlık bilgilerinin elde edilmesini takiben ilgili değişkenler arasında uzun dönemli ilişkilerin geçerli olup olmadığını araştırabilmek amacıyla Pedroni ve Kao eşbütünleşme testleri kullanılmıştır. Her iki analiz bulguları, ilgili değişkenler arasında eşbütünleşik ilişkilerin geçerli olduğunu ortaya koymuştur. Adı geçen sonucun elde edilmesi dolayısıyla, değişkenler arasında sebep-sonuç ilişkilerini belirleyebilmek adına 
Granger nedensellik analizi uygulanmıştır. Nedensellik analizi sonuçları, beklentileri karşılar düzeyde ilgili değişkenler arasında en azından tek yönlü bir nedensellik ilişkisinin geçerli olduğunu ortaya koymuştur. Değişkenler arasındaki nedensellik ilişkilerinin belirlenmesini takiben sabit ve tesadüfi etkili model sonuçları belirlenmeye çalışılmış ve Hausman testi doğrultusunda sabit etkili modellerin daha tutarlı sonuçlar verdiği kanıtlanmıştır. Model tahmin sonuçları, çeşitli regresyon modelleri itibariyle borsa endeksinin bir dönem gecikmeli değeri, döviz kurunun cari değeri, faiz oranının cari ve bir dönem gecikmeli değeri ile enflasyon oranının cari değerinin borsa endeksi üzerinde etkili olduğunu göstermiştir. Dolayısıyla, borsa endeksinin başta döviz kuru olmak üzere, döviz kurunu çeşitli mekanizmalar yardımıyla etkileyen faiz ve enflasyon oranlarından etkilendiğini söylemek olasıdır.

Bu noktada belirtmek gerekir ki, panel veri uygulaması nedeniyle dikkate alınan 12 ülke için ortak sonuçlara ulaşılmaktadır. Ancak adı geçen 12 ülkenin tamamının ortak özellikler sergilemekte olduğunu kabul etmek o kadar kolay değildir. Dikkate alınan ülkelerin her biri farklı yapısal özellikler sergileyebilmekte ve farklı koşullarda durağan durum dengesine ulaşabilmektedir. Dolayısıyla, ülkelerin teker teker analiz edilmesi halinde değişik sonuçlar elde edilebileceği de gözden kaçırılmaması gereken bir hususu yansıtmaktadır. Bu konuda ve zaman serisi analizleri tekniğiyle yapılacak olan uygulamalı çalışmalar, farklı sonuçların elde edilmesini sağlayabilecektir.

Elde edilen bulgular bir bütün olarak değerlendirildiğinde, kırılgan finansal piyasa yapısından kurtulabilmek için temel makroekonomik göstergeler üzerinde istikrar sağlanmasının hayatı bir önem taşıdığı söylenebilmektedir. Özellikle döviz kurlarının finans piyasalarındaki temel determinantlardan biri olduğu göz önünde bulundurulduğunda, döviz kurlarına etki edebilecek olan diğer faktörler itibariyle de istikrarlı bir yapılanmanın gerekliliği ortaya çıkmaktadır. Bu süreci etkileyen başat faktörler olarak değerlendirilen faiz ve enflasyon oranlarının tetikleyici yapısı dikkate alındığında, söz konusu iki değişkenin gerek reel ve gerekse finansal piyasalardaki etkin gücü rahatllkla görülmektedir. Model kapsamındaki ülkeler göz önüne alındığında, analizlerin temelini oluşturan döviz kurlarının yatırımcılar için en belirleyici faktör olduğu gözlenmiş ve menkul kıymet piyasalarına yönelimlerini ilgili faktöre göre oluşturdukları görülmüştür. Diğer taraftan, faiz oranları ile birleştirildiğinde Portföy Teorisi'nin vurguladığı sürecin işlediği anlaşılmış, kâr güdüsü ile hareket eden fonların kendilerine en yüksek getiriyi sağlayacak alana hareket ettikleri gözlenmiştir. Diğer taraftan, kendilerini enflasyonist etkilerden korumak isteyen yatırımcılar için Tobin Etkisi'nin varlı̆̆ kantlanarak, yüksek enflasyon dönemlerinde menkul kıymet piyasalarının güvenli bir liman olarak değerlendirildiği anlaşılmıştır. Buradan hareketle, reel ve finansal piyasaların birbirleri ile olan sıkı etkileşimini söylemek olasıdır. Bir piyasa yapısının diğeri üzerinde mutlak bir etkiye sahip olduğunu gösteren böyle bir yapılanma sürükleyici ve yıkıcı olabildiğinden dolayı, her piyasa türü için istikrarın sağlanması ve kırılganlıkların önlenmesi en büyük gelişme hedeflerinden biri olmalıdır. Dolayısıyla, 
ekonomik ve finansal piyasa liberalizasyonuna önem veren, hükümet kısitlamalarını kaldırarak piyasaların görünmez el dinamiğini harekete geçiren, mülkiyet ve sözleşme serbestliğine dayanan bir yapılanma ile söz konusu sürece ivme kazandıran, yatırımcılar için belirsizlik ortamını giderebilecek önlemleri alan ve böylece piyasa derinliğini sağlayan yapılanmaların ekonomik ve finansal gelişim sürecine katkıda bulunacağını söylemek mümkündür.

\section{KAYNAKLAR}

Abdalla, I. S. A. - Murinde, V. (1997), "Exchange Rate and Stock Price Interactions in Emerging Financial Markets: Evidence on India, Korea, Pakistan and the Philippines”, Applied Financial Economics, Vol: 7, pp. 25-35.

Aggarwal, R. (1981), "Exchange Rates and Stock Price: A Study of the US Capital Markets under Floating Exchange Rates", Akron Business and Economic Review, Vol: 12, pp. 7-12.

Alagidede, P. - Panagiotidis, T. - Zhang, X. (2010), "Causal Relationship between Stock Prices and Exchange Rates”, Stirling Economics Discussion Paper, No: 2010-05.

Aslan, N. (2007). "Dünya Ekonomisinde Gelişmeler: Küreselleşme”, Küçükahmetoğlu, O. Tüylüoğlu, Ş. - Çestepe, H. (Ed.), Ekonomik Entegrasyon: Küresel ve Bölgesel Yaklaşım, Ekin Yayınevi, Bursa,ss. 5-22.

Aslanoğlu, S. (2008), “İMKB-100 Endeksi İle Emisyon Hacmi, Döviz Kuru ve Faiz Oranlar1 Arasındaki İlişki: Ampirik Bir Analiz", Muhasebe ve Finansman Dergisi, Sayı: 37, ss. 192-204.

Ayaydın, H. - Dağlı, H. (2012), “Gelişen Piyasalarda Hisse Senedi Getirisini Etkileyen Makroekonomik değişkenler üzerine bir inceleme: Panel Veri Analizi”, Atatürk Üniversitesi İktisadi ve İdari Bilimler Dergisi, Cilt: 26, Sayı: 3-4, ss. 45-65.

Ayvaz, Ö. (2006), "Döviz Kuru ve Hisse Senetleri Fiyatları Arasındaki Nedensellik İlişkisi”, Gazi Üniversitesi İktisadi ve İdari Bilimler Fakültesi Dergisi, Cilt: 8, Sayı: 2, ss. 1-14.

Batori, O. A. - Tsoukalas, D. - Miranda, P. (2010), "Exchange Rates And Equity Markets: Evidence from Some European Countries", The Journal of Applied Business Research, Vol: 26, No: 6, pp. 47-56.

Berke, B. (2012), “Döviz Kuru ve İMKB100 Endeksi İlişkisi: Yeni Bir Test”, Maliye Dergisi, Say1: 163 , ss. 243-257.

Branson, W. H. (1983), “A Model of Exchange-rate Determination with Policy Reaction: Evidence from Monthly Data", NBER Working Paper, No: 1135.

Büberkökü, Ö. (2013), "The Relationship Between Stock Prices And Exchange Rates: Evidence From Developed And Developing Countries", The ISE Review, Vol: 13, No: 52, pp. 1-16. 
Caporale, G. M. - Hunter, J. - Ali, F. M. (2014), “On the Linkages between Stock Prices and Exchange Rates: Evidence from the Banking Crisis of 2007-2010”, International Review of Financial Analysis, Vol: 33, pp. 87-103

Charemza, W. W. - Deadman, D. F. (1993), New Directions in Econometric Practice, Edward Elgar Publishing, UK.

Çınar, S. (2010), “OECD Ülkelerinde Kişi Başına GSYİH Durağan Mı? Panel Veri Analizi”, Marmara Üniversitesi İİBF Dergisi, Cilt: 29, Sayı: 2, ss. 591-601.

Doğukanlı, H. - Özmen, M. - Yücel, E. (2010), “IMKKB’de Sektörel Açıdan Döviz Kuru Duyarlılığının İncelenmesi”, Ç.Ü. Sosyal Bilimler Enstitüsü Dergisi, Cilt: 19, Sayı: 3, ss. 63-86.

Dornbusch, R. - Fischer, S. (1980), "Exchange Rates and the Current Account", Amercian Economic Review, Vol: 70, No: 5, p. 960-971.

Dowrick, S. - Delong, J. B. (2003), "Globalization and Convergence”, (Ed: Bordo, M. D. Taylor, A. M. - Williamson, J. G. (Eds.), University of Chicago Press, USA, pp. 191226.

Elmas, B. - Esen, Ö. (2011), "Hisse Senedi Fiyatları İle Döviz Kuru Arasındaki Dinamik İlişkinin Belirlenmesi; Farklı Ülke Piyasaları İçin Bir Araştırma”, Muhasebe ve Finansman Dergisi, Say1: 52, ss. 153-170.

Erbaykal, E. - Okuyan, H. A. (2007), "Hisse Senedi Fiyatları İle Döviz Kuru İlişkisi: Gelişmekte Olan Ülkeler Üzerine Ampirik Bir Uygulama”, BDDK Bankacılık ve Finansal Piyasalar Dergisi, Cilt: 1, Sayı: 1, ss. 77-89.

Franck, P. - Young, A. (1972), "Stock Price Reaction of Multinational Firms to Exchange Realignments", Financial Management, Vol: 1, No: 3, pp. 66-73.

Granger, C. W. J. (1964), Spectral Analysis of Economic Time Series, Princeton University Press, New Jersey.

Granger, C. W. J. (1969), "Investigating Causal Relations by Econometric Models and CrossSpectral Methods”, Econometrica, Vol: 37, No: 3, pp. 424-438.

Granger, C. W. J. - Newbold, P. (1974), "Spurious Regressions in Econometrics”, Journal of Econometrics, Vol: 2, No: 2, pp. 111-120.

Granger, C. W. J. - Bwo-Nung, H. - Yang, C. (2000), “A Bivariate Causality Between Stock Prices and Exchange Rates: Evidence From Recent Asian Flu”, The Quarterly Review of Economics and Finance, Vol: 40, No: 3, pp. 337-354.

Güngör, B. - Yerdelen Kaygın, C. (2015), "Dinamik Panel Veri Analizi İle Hisse Senedi Fiyatını Etkileyen Faktörlerin Belirlenmesi”, Kafkas Üniversitesi İktisadi ve İdari Bilimler Fakültesi Dergisi, Cilt: 6, Sayı: 9, ss. 149-168

Hausman, J. A. - Taylor, W. E. (1981), "Panel Data and Unobservable Individual Effects". Econometrica, Vol: 49, No: 6, pp. 1377-1398. 
İşcan, E. (2011), "Döviz Kurları ve Hisse Senedi Piyasaları Arasındaki Etkileşim: Türkiye Örneği (Aralık 2001-Aralık 2009)”, Elektronik Sosyal Bilimler Dergisi, Cilt: 10, Say1: 35, ss. 237-251.

Kao, C. (1999), "Spurious Regression and Residual-Based Tests for Cointegration in Panel Data", Journal of Econometrics, Vol: 90, No: 1, pp. 1-44.

Kaya, V. - Yılmaz, Ö. (2006), "Bölgesel Enflasyon Bölgesel Büyüme İlişkisi: Türkiye İçin Zaman Serisi ve Panel Veri Analizleri”, İktisat İşletme ve Finans, Cilt: 21, Sayı: 247, ss. $62-78$.

Köse, O. (2003), “Küreselleşme Sürecinde Devletin Yapısal ve İşlevsel Dönüşümü”, Sayıştay Dergisi, Cilt: 49, ss. 3-46.

Kutlar, A. (2007), Ekonometriye Giriş. 1. Baskı, Nobel Yayınları, Ankara.

MacKinnon, J. G. (1991), “Critical Values for Cointegration Tests”, Engle, R.F. - Granger, C.W.J. (Eds.), Long-Run Economic Relationship: Readings in Cointegration, Oxford University Press, New York, pp. 267-276.

Özmen, M. (2007), "Farklı Döviz Kuru Rejimleri Altında Hisse Senetleri Fiyatları İle Döviz Kurları Arasındaki İlişkinin Ekonometrik Analizi”, Ç.Ü. Sosyal Bilimler Enstitüsü Dergisi, Cilt: 16, Say1: 1, ss.519-538.

Pedroni, P. (1999), "Critical Values for Cointegration Tests in Heterogeneous Panels with Multiple Regressors", Oxford Bulletin of Economics and Statistics, Vol: 61, No: S1, pp. 653-670.

Rahman, M. L. - Uddin, J. (2009), "Dynamic Relationship between Stock Prices and Exchange Rates: Evidence from Three South Asian Countries", International Business Research, Vol: 2, pp. 167-174.

Richards, N. D. - Simpson, J. (2009), "The Interaction between Exchange Rates and Stock Prices: An Australian Context", International Journal of Economics and Finance, Vol: 1, No: 1, pp. 3-23.

Savaş, İ. - Can, İ. (2011), "Euro- Dolar Paritesi ve Reel Döviz Kuru'nun İMKB-100 Endeksi'ne Etkisi”, Eskişehir Osmangazi Üniversitesi İktisadi ve İdari Bilimler Fakültesi Dergisi, Cilt: 6, Say1: 1, ss. 323- 339.

Sevinç, E. (2014), “Makroekonomik Değişkenlerin, BİST-30 Endeksinde İşlem Gören Hisse Senedi Getirileri Üzerindeki Etkilerinin Arbitraj Fiyatlama Modeli Kullanarak Belirlenmesi”, İstanbul Üniversitesi İşletme Fakültesi Dergisi, Cilt: 43, Sayı: 2, ss. 271-292.

Smyth, R. - Nandha, M. (2003), "Bivariate Causality Between Exchange Rates and Stock Prices in South Asia”, Applied Economic Letters, Vol: 10, pp. 699-704.

Şahin, İ. - Sekmen, F. (2013), " Türkiye'de Döviz Kuru Belirsizliğinin Hisse Senedi Getirilerine Etkisi”, Dumlupınar Üniversitesi Sosyal Bilimler Dergisi, Sayı: 36. 
Şentürk, M. - Dücan, E. (2014), “Türkiye'de Döviz Kuru-Faiz Oranı ve Borsa Getirisi İlişkisi: Ampirik Bir Analiz”, Business and Economics Research Journal, Vol: 5, No: 3, ss. 6780.

Taylor, A. M. (2004), "Global Finance: Past and Present", Finance and Development, Vol: 41, No: 1, pp. 28-31.

Tokat, H. A. (2013), “Altın, Döviz ve Hisse Senedi Piyasalarında Oynaklık Etkileşimi Mekanizmasının Analizi”, İstanbul Üniversitesi Siyasal Bilgiler Fakültesi Dergisi, Say1: 48, ss.151-162.

Tsagkanos, A. - Siriopoulos, C. (2013)," A Long-Run Relationship Between Stock Price Index And Exchange Rate: A Structural Nonparametric Cointegrating Regression Approach", Journal of International Financial Markets, Institutions and Money, Vol: 25, pp. 106-118.

Yau, H. Y. - Nieh, C. C. (2006), "Interrelationships among Stock Prices of Taiwan and Japan and NTD/Yen Exchange Rate", Journal of Asian Economics, Vol. 17, No: 3, pp. 535552.

Yıldız, A. (2014), "BIST 100 Endeksi İle Alternatif Yatırım Araçlarının İlişkisi”, Süleyman Demirel Üniversitesi İktisadi ve İdari Bilimler Fakültesi Dergisi, Cilt: 19, Sayı: 2, ss. 39-56.

Yüce Akınc1, G. - Akıncı, M. - Yılmaz, Ö. (2013), "İktisadi Küreselleşme ve Finansal Özgürlükler Arasındaki İlişki: Bir Panel Veri Analizi”, Akademik Araştırmalar ve Çalışmalar Dergisi, Cilt: 5, Sayı: 9, ss. 80-99.

Yücel, E. - Özmen, M. (2010), "Faiz Oran1, Döviz Kuru Ve Borsa Endeksi Nedensellik İlişkisi: 1989-2009 Türkiye Uygulaması”, Muhasebe Bilim Dünyası Dergisi, Cilt: 12, Sayı: 3, ss. 213-244. 